\title{
Changes in integrin-positive cells and T cell subpopulations in the peripheral blood and intestine of calves fed soya protein*
}

\author{
M. Brna' ${ }^{1}$ V. Revajová2 ${ }^{2}$ R. Žitňan ${ }^{1,4}$, M. Levkut Jr.', M. Baran ${ }^{3}$ \\ and M. Levkut ${ }^{2}$ \\ ${ }^{I}$ Animal Production Research Centre Nitra \\ Komenského 73, Košice, Slovak Republic \\ ${ }^{2}$ University of Veterinary Medicine and Pharmacy \\ Komenského 73, Košice, Slovak Republic \\ ${ }^{3}$ Institute of Animal Physiology, Slovak Academy of Sciences \\ Šoltésovej 4-6, Košice, Slovak Republic
}

(Received 1 February 2010; revised version 29 July 2010; accepted 16 August 2010)

\begin{abstract}
In order to examine the relation of known intestinal lesions to changes in T-cell phenotypes and integrin expression, 16 male 10-day-old Holstein calves were divided into two groups. For 28 days of the experiment, eight males were fed NutriMilk in which $50 \%$ of the crude protein was soya protein, and eight control animals, with NutriMilk containing only milk casein. The animals fed soya protein showed shorter jejunal villi with a corrugated surface and deeper crypts compared with the control calves. A higher density of CD8+ cells in the intestinal mucosa and a decrease of these cells in peripheral blood were found in calves fed soya protein. The number of CD11b-positive cells was decreased in the peripheral blood of calves fed soya protein. Lower expression of integrin could be related to the appearance of non-mature polymorphonuclear cells. It is not clear if the decrease in CD11b expression on blood cells could also be influenced by milk replacer, i.e. soya protein.
\end{abstract}

KEY WORDS: calves, soya protein, intestine, immunity, integrin, T cells

\footnotetext{
* Supported by the Grant Agency for Science of Slovak Republic VEGA - 1/0044/08, 1/0609/09, and APVV-20-041605

${ }^{4}$ Corresponding author: e-mail: rudolf.zitnan@gmail.com
} 


\section{INTRODUCTION}

For economic reasons calf rearing is now conducted using substitution of milk protein by milk replacers. In addition to foreign lipids, suckling preruminants are given primarily foreign proteins, such as soya protein. Soya proteins have been shown, however, to reduce growth and feed efficiency in young ruminants when compared with whole milk or casein diets (Drackley et al., 2006). Partial replacement of milk protein by soya protein results in morphological changes of the intestinal structure, including reduced villous circumference and height in the jejunum of kids (Žitňan et al., 2005; Schönhusen et al., 2010).

Small intestine intraepithelial lymphocytes (IEL) represent a unique population of cells. In calves, T lymphocytes, CD4 and CD8 cells, constitute a large population of IEL (Wyatt et al., 1999). IEL are cytolytic (Sydora et al., 1993) and upon activation, express cytokines consistent with a type I (cytotoxic) immune response (Yamamoto et al., 1993; Gelfanov et al., 1995). In addition to T lymphocytes, small intestinal IEL isolated from neonatal calves contain a population of sIgM+ lymphocytes. The reduction of jejunal villi is associated with a dramatic infiltration of the lamina propria by $\mathrm{B}$ and $\mathrm{T}$ lymphocytes after feeding of preruminant calves with heated soyabean flour (Lallès et al., 1996).

Local inflammatory sites increase the number of phagocytes via inflammatory mediators and interleukins (Arnaout, 1990). However, effective neutrophil recruitment to the site of infection requires adhesion molecules from the selectin and $\beta 2$ integrin families. The most important $\beta 2$ integrins involved in neutrophil recruitment into inflamed tissue are $\mathrm{CD} 11 \mathrm{~b} / \mathrm{CD} 18$ and $\mathrm{CD} 11 \mathrm{c} / \mathrm{CD} 18$ (Tizzard, 2009).

The present study was conducted to examine morphological changes of the jejunal villi in relation to the reactivity of peripheral and intraepithelial lymphocytes. Moreover, we evaluated integrin-positive cells in order to find a possible effect of soya protein on the activity of phagocytes in preruminats calves.

\section{MATERIAL AND METHODS}

\section{Animals, diets and experimental procedures}

Sixteen Holstein bull calves were enrolled onto the study at the age of 10 days. They were born and maintained at the same commercial farm. After birth the calves stayed with their mothers to suck colostrum and milk. At the beginning of the experiment they were randomly assigned to dietary treatment groups of 8 bulls each. The animals were housed in individual boxes in an ambient temperature of 
approximately $16^{\circ} \mathrm{C}$ with continuous access to fresh water. Calves were weighed weekly prior to the morning feeding.

The calves of group I (control) were administered a milk feed mix, NutriMilk (MP), containing milk proteins, and the calves of group II (experimental) were given NutriMilk (SP), containing plant proteins, i.e. $50 \%$ of soya proteins in the milk drink. The milk feed mixes were diluted at a ratio of $125 \mathrm{~g}$ of mix per litre of water. The producer of the mix used in this experiment was Biofaktory, Ivanka pri Dunaji (Slovakia). The chemical composition and components of the mix are given in Table 1. Both groups of calves were fed three times per day only the milk drink; the amount was gradually increased according to their age from 61 in week 2 of age to 101 in week 6 of age (an increase by 11 every week).

Table 1. Chemical composition and components of milk feed mixtures for calves

\begin{tabular}{lcc}
\hline Itcm & NutriMilk MP' & NutriMilk SP2 $^{2}$ \\
\hline Dry matter, g/kg & 968 & 964 \\
Crude protein, g/kg of DM & 220 & 220 \\
Crude fat, g/kg of DM & 150 & 150 \\
Crude fibre, g/kg of DM & 3 & 6 \\
Ash, g/kg of DM & 80 & 88 \\
ME, MJ/kg of DM & 17.87 & 17.75 \\
\hline
\end{tabular}

NutriMilk MP - dried whey, dried buttermilk, full cream dried milk, coconut and palm oil, dextrose, vitamin-mineral premix; ${ }^{2}$ NutriMilk SP - dried whey, wheat gluten, soya protein concentrate (Hamlet Protein A/S, Horsens, DK), coconut and palm oil, dextrose, vitamin-mineral premix

During the experiment blood was sampled from the jugular vein of the calves into tubes containing disodium-EDTA $\left(1.5 \mathrm{mg} \cdot \mathrm{ml}^{-1}\right.$ blood $)$. Blood was sampled for the first time at the age of 7 days before the beginning of the experiment (sampling 0 ), and then twice in two-week intervals during the experiment (samplings 1 and 2). On day 28 of the experiment the calves were sacrificed and samples of the individual parts of the intestinal tract (duodenum, jejunum and ileum) were collected.

\section{Analytical procedures}

White blood cell (WBC) count. Leukocyte counts were determined using a routine laboratory method with a Bürker chamber and Türk solution (475 $\mu 1$ solution plus $25 \mu \mathrm{l}$ blood). Differential cell counts of 100 cells per slide were done by light microscopy at $1000 \mathrm{x}$ magnification using blood smears and after staining the cells with Hemacolor kit (Merck, Germany). Numbers (actual count) of different types of WBC were determined as follows: total leukocyte count $\mathrm{x}$ proportion of differential cells counted $(\%) / 100$. 
Flow cytometry of blood. The indirect immunofluorescence method and whole blood for phenotyping of lymphocyte subpopulations were used. Primary unlabelled mouse anti-bovine monoclonal antibodies (donated by Illrad, Kenya) are summarized in Table 2. The secondary antibody, a polyclonal goat antimouse FITC conjugated immunoglobulin $\mathrm{F}\left(\mathrm{ab}^{\prime}\right)_{2}$ fragment (Dako, Denmark), was used for staining lymphocytes for indirect immunofluorescence at a working dilution of 1:50 with phosphate-buffered saline and $0.1 \%$ sodium azide $\left(\mathrm{PBS}+\mathrm{NaN}_{3}\right)$.

Table 2. Primary unlabelled mouse-anti-bovine monoclonal antibodies used in the experiment

\begin{tabular}{llll}
\hline MoAbs & \multicolumn{1}{c}{ Specificity } & Isotype & Dilution \\
\hline IL-A30 & IgM & IgG1 & $1: 2500$ \\
IL-A12 & CD4 & IgG2 & $1: 2000$ \\
IL-A51 & CD8 & IgG1 & $1: 1000$ \\
IL-A42 & CD2 (pan T) & IgG & $1: 1000$ \\
IL-A29 & BoWC1(TCR $\gamma / \delta)$ & IgG2b & $1: 1000$ \\
IL-A46 & CD11c & IgM & $1: 1000$ \\
Il-A130 & CD11b & IgG2a & $1: 1000$ \\
\hline
\end{tabular}

Whole blood $(100 \mu 1)$ was incubated with a working dilution of unlabelled primary antibody for $15 \mathrm{~min}$ at room temperature in the dark. Erythrocytes were lysed using a lysing solution $\left(8.3 \mathrm{~g} \mathrm{NH}_{4} \mathrm{Cl}, 1 \mathrm{~g} \mathrm{KHCO}_{3}, 200 \mathrm{mM}\right.$ EDTA dissolved in $1 \mathrm{l}$ distilled water) for $10 \mathrm{~min}$ at room temperature in the dark. After lysis the samples were centrifuged at $145 \mathrm{~g}$ for $5 \mathrm{~min}$, and washed twice in PBS. The pellets were mixed with $25 \mu \mathrm{l}$ of secondary antibody and incubated $30 \mathrm{~min}$ at $+4^{\circ} \mathrm{C}$. After staining the cells were washed once in PBS and resuspended in $0.2 \mathrm{ml}$ of PBS containing $0.1 \%$ paraformaldehyde. For each cell suspension, cell population acquisition and analysis were carried out using a flow cytometer with a $15 \mathrm{mV}$ argon laser (498 nm, FACScan, Becton Dickinson, Germany). For acquisition a live gate was drawn around the mononuclear cell population containing the lymphocytes. Fluorescence data were collected on at least 10000 lymphocytes and analysed using the Becton Dickinson Cell Quest (Germany). For each marker, the relative percentage of fluorescent positive cells within this gate was recorded by dot-plot analysis. The numbers of lymphocytes in each subpopulation were computed as follows: actual lymphocyte counts $\mathrm{x}$ relative size of subpopulation $(\%) / 100$.

Immunohistochemistry. Examination of intestinal CD3 positive cells was done with polyclonal rabbit anti-human T cell CD3 antibody (at a dilution of 1:300, Dako, Denmark) on paraffin sections described by Tomková et al. (2002). Frozen sections were used for evaluation of ileal CD8+ cells by mouse anti-bovine monoclonal antibody (Table 2). The pieces of intestine $(1 \mathrm{~cm})$ were put into PBS, held on crushed ice, frozen and cut in a Cryocut $\mathrm{E}$ (Reichert, Germany) at $-24^{\circ} \mathrm{C}$. 
Frozen $7 \mu \mathrm{m}$ sections fixed in cold acetone and rinsed in PBS were incubated with unlabelled primary monoclonal antibody for $1 \mathrm{~h}$. A biotin-streptavidin amplified peroxidase detection system (Biogenex, USA) was used to detect a positive reaction. All incubations were done at room temperature; between the two consecutive $1 \mathrm{~h}$ incubations the sections were rinsed three times with PBS; it was also used instead of monoclonal antibodies as a negative control. The specific colour reaction was developed for $5 \mathrm{~min}$ with $3.5 \mathrm{mmol} \cdot \mathrm{1}^{-1} 3,3^{\circ}$-diaminobenzidine (Sigma, Germany), and $30 \mathrm{ppm}$ hydrogen peroxide in $200 \mathrm{mmol} \cdot \mathrm{l}^{-1}$ Tris/HCl (pH 7.6). The sections were counterstained with haematoxylin and mounted into Entellan (Merck, Germany).

Intestinal morphometry. Intestinal tissue $\left(1 \mathrm{~cm}^{2}\right)$ from the duodenum, jejunum and ileum was fixed in $4 \%$ neutral formaldehyde solution. After being rinsed in water, the samples were dehydrated in a graded series of ethanol $(30,50,70$, $90 \%$ and absolute ethanol), cleared in benzene, saturated with and embedded in paraffin. Sections of $5 \mu \mathrm{m}$ thickness ( 10 slices of each sample) were stained with haematoxylin/eosin and observed under a light microscope. The height of 30 villi and depth of 30 crypts were determined by the computer-operated Image $C$ picture analysis system (Imtronic GmbH, Berlin, Germany) and the IMES (interactive measurement) analysis programme, by using a colour video camera (SONY 3 $\mathrm{CCD}$, Sony Electronics Ltd., Tokyo, Japan) and a light microscope (Axiolab, Carl Zeiss AG, Jena, Germany).

Scanning electron microscopy. Tissue samples of $0.5 \mathrm{~cm}^{2}$ were cut from the jejunum and fixed in a mixture of $2 \%$ paraformaldehyde and $2.5 \%$ glutaraldehyde in sodium cacodylate buffer ( $\mathrm{pH} 7.2$ ). After washing in this buffer they were postfixed in $1 \%$ osmic oxide and dehydrated through a graded series of ethanol, placed in acetone and, finally, critical-point dried in liquid $\mathrm{CO}_{2}$. Samples were then coated with gold at a thickness of $20 \mathrm{~nm}$ at $4^{\circ} \mathrm{C}$. Thus prepared samples were examined using a JOEL JEM-100 CX II electron microscope (Joel Ltd., Akishima, Japan) with an ASID-4D high resolution scanning system at an accelerating voltage of $15 \mathrm{kV}$.

\section{Statistical analyses}

Statistical analyses were carried out using Microsoft Excel and the unpaired Student's $t$-test. The results are expressed as mean values \pm SD. Mean differences were considered significant if $\mathrm{P}<0.05$. 


\section{RESULTS}

The animals were clinically healthy and daily body weight gain (milk protein $784 \pm 73 \mathrm{~g}$; soya protein $763 \pm 63 \mathrm{~g}$ ) was not different between the dietary groups.

Small intestine morphometry and morphology of the jejunum. Villi height was lower $(\mathrm{P}<0.05)$ in preruminant calves fed soya protein than in those fed milk protein. By contrast, the depth of the crypts was higher $(\mathrm{P}<0.05)$ in calves fed soya protein (Table 3 ). Light microscopy did not show alteration of the mucosa in the small intestine of either group. Scanning electron microscopy did, however, reveal a corrugated surface of the villi in the jejunum and a tendency to blend in the experimental group fed soya protein. The villi of this group were shorter and less uniform (Figure 1A). The villi of the jejunum were finger-shaped, uniform, and higher in control animals (Figure 1B).

Table 3. Height of villi and depth of crypts in the small intestine of calves fed milk protein (NutriMilk MP) and soya protein (NutriMilk SP)

\begin{tabular}{|c|c|c|c|c|}
\hline \multirow{3}{*}{$\begin{array}{l}\text { Small intestine } \\
\text { parts }\end{array}$} & NutriMilk MP & NutriMilk SP & NutriMilk MP & NutriMilk SP \\
\hline & \multicolumn{4}{|c|}{ sampling } \\
\hline & \multicolumn{2}{|c|}{ height of villi, $\mu \mathrm{m}$} & \multicolumn{2}{|c|}{ depth of crypts, $\mu \mathrm{m}$} \\
\hline Duodenum & $663 \pm 36$ & $586 \pm 43$ & $242 \pm 18$ & $279 \pm 19$ \\
\hline Jejunum & $735 \pm 42^{a}$ & $591 \pm 38^{b}$ & $226 \pm 16^{a}$ & $287 \pm 17^{b}$ \\
\hline Ileum & $578 \pm 31$ & $532 \pm 27$ & $281 \pm 22$ & $315 \pm 24$ \\
\hline
\end{tabular}

values are means $\pm \mathrm{SD}$; specific superscripts in row - significant differences ${ }^{\text {ab }} \mathrm{P}<0.05$
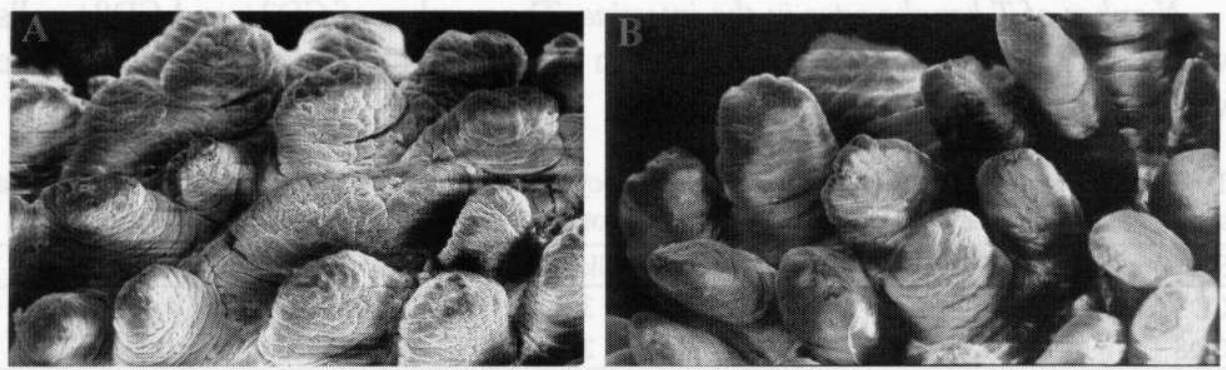

Figure 1. Scanning electron microscopy $(250 \mathrm{x})$ of jejunal intestinal villi in calves fed soya protein (A - NutriMilk SP) and milk protein (B - NutriMilk MP)

Peripheral blood cells - counts and immunophenotyping. Values of peripheral white blood cells were not changed in either group (Table 4). Phenotyping of lymphocytes by flow cytometry (Table 5) did, however, show a decrease of CD8+ cells $(\mathrm{P}<0.05)$ in both samplings in calves fed soya protein compared with control animals. Similarly, the number of cells bearing CD11b was lower $(\mathrm{P}<0.05)$ 


\section{MORPHOLOGICAL CHANGES OF THE JEJUNAL VILLI IN CALVES}

in the first sampling in the calves fed soya protein than in those fed milk protein. A similar trend $(\mathrm{P}<0.08)$ was observed in the second sampling.

Table 4. Numbers of peripheral white blood cells $\left(\mathrm{G} \cdot l^{-1}-1 \cdot 10^{9} \cdot l^{-1}\right.$; average \pm SD) in calves fed milk protein (NutriMilk MP) and soya protein (NutriMilk SP)

\begin{tabular}{|c|c|c|c|c|c|c|}
\hline \multirow{3}{*}{ Cells } & \multicolumn{3}{|c|}{ NutriMilk MP } & \multicolumn{3}{|c|}{ NutriMilk SP } \\
\hline & \multicolumn{6}{|c|}{ sampling ${ }^{1}$} \\
\hline & 0 & 1 & 2 & 0 & 1 & 2 \\
\hline Leukocytes & $8.5 \pm 3.5$ & $\overline{9.3} \pm 2.6$ & $9.2 \pm 1.4$ & $7.5 \pm 2.4$ & $8.7 \pm 1.8$ & $9.3 \pm 2.5$ \\
\hline Lymphocytes & $5.2 \pm 2.3$ & $6.6 \pm 2.3$ & $6.5 \pm 1.4$ & $4.9 \pm 1.5$ & $5.6 \pm 1.3$ & $5.9 \pm 2.1$ \\
\hline Neutrophils & $3.1 \pm 1.3$ & $2.5 \pm 1.0$ & $2.7 \pm 1.7$ & $2.4 \pm 0.9$ & $2.8 \pm 1.3$ & $2.7 \pm 1.1$ \\
\hline Monocytes & $0.2 \pm 0.1$ & $0.3 \pm 0.1$ & $0.1 \pm 0.1$ & $0.2 \pm 0.1$ & $0.2 \pm 0.1$ & $0.2 \pm 0.1$ \\
\hline
\end{tabular}

${ }^{1} 0$ - at $7 \mathrm{~d}$ before start of study; 1 - at $14 \mathrm{~d}$ and 2 - at $14 \mathrm{~d}$ after start of study

Table 5. Absolute counts of lymphocyte subpopulations (actual counts, $G \cdot l^{-1}+1 \cdot 10^{9} \cdot \mathrm{l}^{-1}$; means $\pm \mathrm{SD}$ ) in calves fed milk protein (NutriMilk MP) and soya protein (NutriMilk SP)

\begin{tabular}{|c|c|c|c|c|c|c|}
\hline \multirow{3}{*}{ Subpopulations } & \multicolumn{3}{|c|}{ NutriMilk MP } & \multicolumn{3}{|c|}{ NutriMilk SP } \\
\hline & \multicolumn{6}{|c|}{ sampling } \\
\hline & 0 & 1 & 2 & 0 & 1 & 2 \\
\hline$\overline{\mathrm{CD} 2}$ & $2.81 \pm 1.26$ & $3.07 \pm 1.17$ & $2.93 \pm 0.88$ & $2.66 \pm 0.69$ & $2.41 \pm 0.78$ & $2.80 \pm 1.14$ \\
\hline CD4 & $2.78 \pm 1.41$ & $2.88 \pm 1.04$ & $2.89 \pm 0.48$ & $2.56 \pm 0.68$ & $2.33 \pm 0.64$ & $2.62 \pm 1.06$ \\
\hline CD8 & $0.87 \pm 0.38$ & $0.96 \pm 0.32^{\mathrm{a}}$ & $0.95 \pm 0.29^{\mathrm{a}}$ & $0.66 \pm 0.19$ & $0.60 \pm 0.18^{\mathrm{b}}$ & $0.64 \pm 0.21^{b}$ \\
\hline IgM & $0.94 \pm 0.46$ & $2.58 \pm 1.06$ & $2.45 \pm 0.99$ & $0.97 \pm 0.44$ & $2.32 \pm 0.66$ & $2.15 \pm 1.00$ \\
\hline BoWCl & $1.08 \pm 0.52$ & $1.19 \pm 0.56$ & $1.24 \pm 0.53$ & $1.17 \pm 0.55$ & $1.38 \pm 0.62$ & $1.20 \pm 0.55$ \\
\hline CD1lb & ND & $0.85 \pm 0.22^{\mathrm{a}}$ & $0.93 \pm 0.35$ & ND & $0.61 \pm 0.05^{\mathrm{h}}$ & $0.65 \pm 0.08$ \\
\hline CDIle & ND & $0.83 \pm 0.26$ & $0.49 \pm 0.15$ & ND & $0.64 \pm 0.19$ & $0.44 \pm 0.18$ \\
\hline
\end{tabular}
specific superscripts in row $=$ significant differences ${ }^{\text {ab }} \mathrm{P}<0.05$; expalantion of sampling see Table 4

Number of $T$ lymphocytes in the intestine. The number of CD3+ and CD8+ cells was higher $(\mathrm{P}<0.05)$ in the villi of the ileum in the calves fed soya protein than in the villi of the control ileum (Table 6).

Table 6. Number of CD3 and CD8 positive T lymphocytes in ileum of calves (average from 10 villi per a sample) fed milk protein (NutriMilk MP) and soya protein (NutriMilk SP)

\begin{tabular}{lcc}
\hline Subpopulations & NutriMilk MP & NutriMik SP \\
\hline CD3 + T lymphocytes & $48 \pm 3$ & $52 \pm 4$ \\
CD8 + T lymphocytes & $31 \pm 2^{\mathrm{a}}$ & $39 \pm 3^{\mathrm{b}}$ \\
\hline
\end{tabular}

values are means $\pm \mathrm{SD}$; specific superscripts in row $=$ significant differences ${ }^{\text {at }} \mathrm{P}<0.05$

\section{DISCUSSION}

The present observation showing a shortening of the jejunal villi when preruminant calves are fed soya protein is similar to the results of earlier studies. Kelly et al. (1991) and Kelly and Couts (2000) reported decreases in the villi in young pigs subjected to feed restriction, Lallès et al. (1996), in calves fed antigenic heated soyabean flour, 
and Schönhusen et al. (2010) in goats fed soya protein. Finally, the integrity of small intestinal tissue is changed by infectious and non-infectious diseases, including the ruminal drinking syndrome (Van Weeren Keverling Buisman etal., 1988). Compromised surface integrity of jejunal villi was also found by Kuhla et al. (2007) in young goats fed a milk diet containing part soya protein. These changes were related to protein turnover, energy metabolism, cytoskeleton assembly (Kuhla et al., 2007), and altered RNA metabolism (Schönhusen et al., 2007).

Increased $T$ cell density in the jejunum of calves fed partial replacement of casein with soya protein was essentially accounted for by CD8+ cells in the epithelium. These results confirm the implication of a CD8 $+T$ cell-mediated cytotoxicity mechanism at the epithelial level. Similar results were demonstrated by Drèau et al. (1995) and Lallès et al. (1996) in pigs and calves fed heated soyabean protein. Inflammatory damaged tissue increased the release of proinflammatory mediators in the blood (Diez-Fraile et al., 2003) with reaction of the systemic immune response.

The decrease of CD11b-positive peripheral blood cells in calves fed $50 \%$ soya protein seems to be related to the appearance of immature cells in blood. Indeed, it has been shown that CD11b is expressed in a lower percentage of bone marrow immature PMN compared with the mature pool (Van Merris et al., 2002). This rather small population of PMN staining negative for CDIlb might not be able to migrate to the inflammatory tissue. Van Merris et al. (2002) also demonstrated decreased phagocytosis and oxidative burst activity in immature bovine PMN. Our suggestion is supported by the inverse ratio of PMN (day 0 vs 14 of the experiment) in blood of calves fed NutriMilk MP compared with polymorphonuclear cells of calves fed $50 \%$ soya protein (NutriMilk SP). Similarly, it has been reported in humans that immature cells express fewer adhesion molecules (Van Eeden et al., 1997). It is questionable if the decrease of CD1 Ib on the peripheral blood cells can be attributed to the feeding of $50 \%$ soya protein.

Milk has diverse protective, anti-inflammatory and immunostimulating ingredients that influence the immune system of the offspring locally and systemically (Kelleher and Loennerdal, 2001). Bovine colostrum contains concentrations of viable leukocytes similar to those in peripheral blood and $\mathrm{T}$ lymphocytes from the major population of lymphocytes (Liebler-Tenorio et al., 2002).

Soya protein-based diets contain non-nutritive components, e.g., isoflavones (Chen et al., 2005), or a deficit of essential amino acids, such as Thr, Met, Lys (Kanjanapruthipong, 1998). Moreover, milk and colostrum contain the glycoprotein, lactoferin, which has immunomodulation properties (Adlerova et al., 2008).

The decrease of CD1 lb-positive peripheral blood cells in calves fed $50 \%$ soya protein indicates impaired migration of neutrophils to the site of infection and 
vulnerability to a number of enteric diseases. Reduced surface expression of CD11/ CD18 is also observed in neonatal granulocytes (Arnaout, 1990), and decreases the resistance to mastitis of cows with a specific genotype of the chemokine receptor CXCR2 (Rambeaud and Pighetti, 2005).

\section{CONCLUSIONS}

Feeding calves soya protein in the amount of $50 \%$ of total dietary crude protein confirmed the decrease of jejunal villi and alteration of their surface structure. The higher density of CD8+ cells in jejunal mucosa points to inflammatory processes in that site and can be the result of increasing migration of CD8+ lymphocytes from peripheral blood. The decrease of CD11b-positive peripheral blood cells can lead to a higher incidence of enteric and other diseases of calves fed $50 \%$ soya protein. Whether non-milk protein sources can lead to changes in other cell surface receptors on immunocompetent cells of the preruminant calf requires further investigation.

\section{REFERENCES}

Adlerova L., Bartoskova A., Faldyna M., 2008. Lactoferrin: a review. Vet. Med.-Czech 53, 457468

Arnaout M.A., 1990. Structure and function of the leukocyte adhesion molecules CDI1/CDI8. Blood 75, 1037-1050

Chen A.C., Berhow M.A., Tappenden K.A., Donovan S.M., 2005. Genistein inhibits intestinal cell proliferation in piglets. Pediat. Res. 57, 192-200

Diez-Fraile A., Meyer E., Duchateau L., Burvenich C., 2003. L-selectin and $\beta 2$ integrin expression on circulating bovine polymorphonuclear leukocytes during endotoxin mastitis. J. Dairy Sci. 86, 2334-2342

Drackley J.K., Blome P.M., Barlett K.S., Bailey K.L., 2006. Supplementation of 1\% L-Glutamine to milk replacer does not overcome the growth depression in calves caused by soy protein concentrate. J. Dairy Sci. 89, 1688-1693

Dreau D., Lallès J.P., Toullec R., Salmon H., 1995. B and T lymphocytes are enhanced in the gut of piglets fed heat-treated soyabean proteins. Vet. Immunol. Immunopathol. 47, 69-79

Gelfanov V., Lai Y.-G., Gelfanova V., Dong J.-Y., Su J.-P., Liao N.-S., 1995. Differential requirement of CD28 costimulation for activation of murine CD8+ intestinal intraepithelial lymphocyte subsets and lymph node cells. J. Immunol. 155, 76-82

Kanjanapruthipong J., 1998. Supplementation of milk replacer containing soy protein with threonin methionine and lysine in the diets of calves. J. Dairy Sci. 81, 2912-2915

Kelleher S.L., Loennerdal B., 2001. Immunological activities associated with milk. Adv. Food Nutr. Res. 10, 39-65

Kelly D., Couts G.P., 2000. Early nutrition and the development of immune function in the neonate. Proc. Nutr. Soc. 59, 177-185 
Kelly D., Smyth J. A., MacCracken K.J., 1991. Digestive development of the early weaned pig. 2. Effect of level of food intake on digestive enzyme activity during the immediate post-weaning period. Brit. J. Nutr. $65,181-188$

Kuhla S., Rudolph P.E., Albrecht D., Schönhusen U., Zitnan R., Tomek W., Huber K, Voigt J., Metges C.C., 2007. A milk diet partly containing soy protein does not change growth but regulates jejuna proteins in young goats. J. Dairy Sci. 90, 4334-4345

Lallès J.P., Drèau D., Féménia F., Parodi A. L., Toullec R., 1996. Feeding heated soyabean flour increases the density of $\mathrm{B}$ and $\mathrm{T}$ lymphocytes in the small intestine of calves. Vet. Immunol. Immunopathol. 52, 105-115

Liebler-Tenorio E. M., Ricdel-Caspan G., Pohlenz J.F., 2002. Uptake of colostral leukocytes in the intestinal tract of newborn calves. Vet. Immunol. Immunopathol. 85, 33-40

Rambeaud M., Pighetti G.M., 2005. Impaired neutrophil migration associated with specific bovine CXCR2 genotypes. Infec. Immunity 73, 4955-4959

Schönhusen U., Kuhla S., Rudolph P.E., Zitnan R., Albrecht D., Huber K., Voigt J., Flöte A., Hammon H.M., Metges C.C., 2010. Alterations in the jejunum of young goats caused by feeding soy protein-based diets. J. Anim. Physiol. Anim. Nutr. 94, I-14

Schönhusen U., Kuhla S., Zitnan R., Wutzke K.D., Huber K., Moors S., Voigt J., 2007. Effect of a soy protein-based diet on ribonucleic acid metabolism in the small intestinal mucosa of goat kids. J. Dairy Sci. 90, 2404-2412

Sydora B.C., Mixter P.F., Holcombe H.R., Eghtesady P., Williams K., Amaral M.C., Nel A., Kronenberg M., 1993. Intestinal intraepithelial lymphocytes are activated and cytolytic but do not proliferate as well as other T cells in response to mitogenic signals. J. Immunol. 150, 2179-2191

Tizzard I.R., 2009. Neutrophils and Their Products. Veterinary Immunology, An Introduction. $8^{\text {ht }}$ Edition. Saunders Elsevier, St. Luis, pp. 28-56

Tomková I., Ševčiková Z., Levkut M., Revajová V., Čonková E., Laciaková A., Lenhardt L., 2002. Effect of aflatoxin $B_{1}$ on CD3 $T$ cells and alkaline phosphatase in the intestine of mice. Mycopathologia 154, 15-19

Van Eeden S.F., Miyagashima R., Haley L., Hogg J.C., 1997. A possible role for L-selectin in the release of polymorphonuclear leukocytes from bone marrow. Amer. J. Physiol. 272, 1717-1724

Van Merris V., Meyer E., Burvenich C., 2002. Functional maturation during bovine granulopoiesis. J. Dairy Sci. 85, 2859-2868

Van Weeren-Keverling Buisman A., Noordhuizen-Stassen E.N., Breukink H.J., Wensing T., Mouwen J.M., 1988. Villus atrophy in ruminal drinking calves and mucosal restoration after reconditioning. Vet. Quart. 10, 164-171

Yamamoto M., Fujihashi K., Beagley K.W., McGhec J.R., Kiyono H., 1993. Cytokine synthesis by intestinal intracpithelial lymphocytes. Both $\gamma / \delta \mathrm{T}$ cell receptor-positive and $\alpha / \beta \mathrm{T}$ cell receptorpositive $T$ cells in the GI phase of cell cycle produce IFN- $\gamma$ and IL-5. J. Immunol. 150, 106-114

Wyatt C.R., Wendy J., Barret E., Brackett J., Davis W.C., Besser T.E., 1999. Phenotypic comparison of ileal intraepithelial lymphocyte populations of suckling and weaned calves. Vet. Immunol. Immunopathol. 67, 213-222

Žitňan R., Kuhla S., Schönhusen U., Voigt J., Levkut M., Revajová V., Tomková I., Brna M., Župčanová M., Hudáková M., 2005. Effects of soya protein intake upon the development of the intestinal tract of suckling kids. Agriculture 51, 30-35 